\title{
Reducing Unemployment in Delta State through Agricultural Extension and Management Programme: A Case Study of Delta State Polytechnic Ozoro
}

\author{
Tibi K.N. and Adaigho D.O.
}

\begin{abstract}
This study was carried out in Delta State to examine, how unemployment in Delta State can be reduced through Agricultural Extension and Management programme. A purposive sampling technique was implored to select all the student of HND 1 and HND11 (2012/2013 session) from the Department of Agricultural Extension and Management .Distribution of respondents were HND I was 35 and HND 11 was 38. Data collected with the questionnaires were carefully assembled. The results obtained were systematically and scientifically organized and presented in tables. The simple percentage was used to present data. Data was analyzed by simple mathematical computation. The findings from the study reveals that: the courses in Agricultural Extension and Management Programme are skill oriented; managerial courses, general studies, communication and computer skills among others are courses taught in Agricultural Extension and Management Programme: computer and communicating skills are necessary skills for managerial and productive potential; the actual problems faced in the program are lack /inadequate equipment and insufficient time for practical works; concerted effort has not been made to remedy the problems encounter in the program; and finally Agricultural Extension and Management programme is practically driven and would help to build managerial and productive skills of its graduates who can either be gainfully employed by government and organization on graduation or be self-employed.
\end{abstract}

\section{Introduction}

In Nigeria, like other developing countries there is an endemic problem of unemployment persistently increasing geometrically with its resulting social and economic vices every year, more graduate are turned out from different universities and other tertiary institutions without adequate provision for job engagement by either the government or private sectors. It is evident that most of our educational programmers, particularly the universities do not encourage or enhance self-development through acquisition of skills for self-reliance. The attendant effects are that these graduates on completion of their education become job seekers instead of being creator of jobs. The research would be a good source of career guidance to many youths as it would help to equip them to the future needs of employers of labour. Generally, education is adjudged to be crucial to economic empowerment because it provides skills and abilities which enable household to secure gainful employment. The CBN report in 2002 of Nigeria Economic and Financial position reviewed that various organizations and institutions such as the National Directorate of Employment (NDE), Poverty Alleviation Programme (PAP), the National Youth Service Corps, Women and Youth Employment Scheme and Better Life Programme for Rural Women established with the aim to eradicate unemployment in Nigeria have not been able to meet its desired goal. Ogunfunminiyi (2005) averred that with the right entrepreneurial skills, good and realistic plan, integrity, probity, honesty and good logical thinking inter-personal attributes and self encouragement many Nigerian graduates can be self employed through the utilization of globalization of informational development and acquisition.

\section{Statement of Problem}

Poverty, resulting from under development and unemployment is almost a recurring decimal in our nation- employment saga in the type and level of education acquired by individuals. Most programmes in our institutions of learning are theoretically oriented. Even when there are some which are practical in nature, the equipment or machines may be lacking or they are obsolete. The result becomes half baked graduate being produced. However, Agricultural Extension and Management programme is designed to solve this ugly menace, as trainees are developed with viable skills that would make them to fit into tomorrow's jobs 


\section{Research Questions}

The study answered the following research questions.

1) What are the courses taught in Agricultural Extension and management programmes in Delta State Polytechnics Ozoro?

2) What are the likely problems of Agricultural Extension and Management programmes?

3) Can this programme help in reducing unemployment menace in Delta State?

\section{Area of Study}

This study was carried out in Delta State Polytechnic Ozoro. Delta State Polytechnic Ozoro is located in Isoko North Local Government Area of Delta state within latitude $5^{\circ} \mathrm{N}$ and lies in the rain forest belt of Nigeria, the area experience rainfall of about 1800 per annum with an average monthly temperature range of $39^{\circ} \mathrm{C}$ to $44^{\circ} \mathrm{C}$. Isoko North Local Government Area is situated in south senatorial district of Delta State. It is bounded to the south by Isoko South Local Government Area, to the north by Ughelli North Local Government Area, to the West by Ndokwa West Local Government Area and to the East by Ndokwa East Local Government Area, all in Delta State. It has a remarkable topography that is void of hill with fertile land that is suitable for crop production and also with a tropical climate marked by dry and wet season for fishery and animal production

\section{Population of the Study}

The population of this study comprised of students of Higher National Diploma Program in the Department of Agricultural Extension and Management Delta State Polytechnic Ozoro.

\section{Sampling Techniques}

A purposive sampling technique was implored to select student of HND 1 and HND11 (2012/2013 session) respectively from the Department of Agricultural Extension and Management.

Distribution of respondents

HND I 35

HND 1138

Data collected from the questionnaires were carefully assembled. The results obtained were systematically and scientifically organized and presented in tables. The simple percentage was used to analyze data.

$$
\frac{\text { Number of response } \quad x}{\text { Total number of response }} \quad \frac{100}{1}
$$

\section{Results and Discussion}

Table 1: Whether the Programme help to build skill in the students

\begin{tabular}{|l|l|l|l|}
\hline Question 1 & Options & Respondents & Percentage 100\% \\
\hline $\begin{array}{l}\text { Is it true that Agric Extension and Management programmes } \\
\text { are aimed at building productive and managerial skills in } \\
\text { students? }\end{array}$ & Yes & 73 & 100 \\
\hline & To & - & - \\
\hline
\end{tabular}

Source: field survey 2013

In table 1 above, a total numbers of seventy three (7) respondents representing $100 \%$ agreed that the programme help to build skills among its graduates. This implies that the programme is skill oriented.

Table 2: courses taught in Agric Extension and Management Programme.

\begin{tabular}{|l|l|l|l|}
\hline Question 2 & Options & Respondents & Percentage 100\% \\
\hline $\begin{array}{l}\text { Are the following courses taught in Agric Extension and } \\
\text { Management programmes: farm business. organisation, farm record } \\
\text { \& account, agric marketing, produce processing, farm mechanisation } \\
\text { farm practice computer, general studies, etc. }\end{array}$ & No & 66 & 90.41 \\
\hline & Total & 7 & 9.59 \\
\hline
\end{tabular}

Source: field survey 2013 
In table 2 above, 66 respondents (representing 90.41\%) agreed that the courses are being taught in the programme, while seven of them $(9.59 \%)$ disagreed. Therefore with the majority response it shows that these courses are being taught at the HND programmes.

Table 3: The necessity of Computer and Communication knowledge

\begin{tabular}{|l|l|l|l|}
\hline Question 3 & Options & Respondents & Percentage 100\% \\
\hline $\begin{array}{l}\text { Do you have computer and } \\
\text { communication knowledge necessary } \\
\text { for productive and managerial skills? }\end{array}$ & Nos & 50 & 68.49 \\
\hline & Total & 23 & 31.51 \\
\hline
\end{tabular}

Source: survey data 2013

In table 3 above about $68 \%$ of respondents have computer and communication skills while $31 \%$ do not have such skills which confirmed that majority of the students are exposed to computer and communication technology for productive and managerial skills necessary for job generation.

Table 4: Likely Problems encountered in the Programme

\begin{tabular}{|l|l|l|}
\hline Variables & Respondents & Percentages \\
\hline Lack/inadequate equipment & 25 & 34.25 \\
\hline Inadequate class-rooms & 23 & 31.51 \\
\hline Insufficient time for practicals & 25 & 34.25 \\
\hline Total & 73 & $100 \%$ \\
\hline
\end{tabular}

Source: field survey 2011

Table 4 reviewed that lack/inadequate equipment and insufficient time for practical, 34 percent each and $32 \%$ for inadequate class-rooms respectively are the problems associated with Agric Extension and Management Programme in Delta State Polytechnic Ozoro.

Table 5: Efforts aimed at solving the Observed Problems

\begin{tabular}{|l|l|l|l|}
\hline Question 5 & Options & Respondents & Percentage 100\% \\
\hline $\begin{array}{l}\text { Have there been any concerted efforts by the } \\
\text { institution to proffer solutions to the problems? }\end{array}$ & Yes & 16 & 32.5 \\
& No & 57 & 67.5 \\
\hline & Total & 40 & 100 \\
\hline
\end{tabular}

Source: field survey 2011

Table 5 above depicts that 16 respondents, representing 32.5\%, agreed that the institution had made some concerted efforts of solving the problems which include sending students to other institutions and organization on field trips, workshops and symposiums. While 57 respondents representing $67.5 \%$ are of the view that concerted efforts have not been made to solve the problems

Table 6 : The Place of Agricultural Extension and Management Programm in Unemployment Reduction

\begin{tabular}{|l|l|l|l|}
\hline Question 6 & Options & Respondents & Percentage 100\% \\
\hline $\begin{array}{l}\text { Can Agricultural Extension \& Management Programm help in reducing } \\
\text { unemployment rate in Delta State? }\end{array}$ & Yes & 69 & 94.52 \\
& No & 4 & 5.48 \\
\hline & Total & 73 & 100 \\
\hline
\end{tabular}

Source: field survey 2011

From table 5 above 69 of the respondents (90\%) affirmed that the programme would help to reduce unemployment as its graduates can either be employed or self-reliant. But the other 4 respondents (5\%) disagreed that the programme can reduce unemployment. 


\section{Findings}

The finding from the study reveals:

(1) That the course in Agricultural Extension and Management Programme is skill oriented

(2) That managerial courses, general studies, communication and computer among others are courses taught in Agricultural Extension and Management Programme

(4) That computer and communicating are necessary skills for managerial and productive potential

(5) That the actual problems faced in the program are lack /inadequate equipment and insufficient time for practical works.

(6) That concerted effort has not been made to remedy the problems encounter in the program.

(7) That graduates of the program, can either be gainfully employed by government, organizations or selfemployed.

(8) That the study of the programme would help in reducing unemployment in Delta State.

\section{Conclusion}

Agricultural Extension and Management Programme is practically driven and helps to build managerial and productive skills of its graduates who can either be gainfully employed by government, organization or self-employed on graduation.

\section{Recommendations}

Based on the results of the study, the following recommendations were made:

(1) That since the programme is a skill oriented course of study, efforts should be made to encourage students to choose Agricultural Extension and Management programme as a course of study in order to equip them for future jobs.

(2) That efforts should be made at equipping the laboratory of the programme with sufficient equipment for practical work

(3) That management should always make appraisal and take inventories periodically in order to remedy observed deficiencies

(4) That graduates of the programs should be helped financially in form of micro-credit or loan to help them establish on their own as this would help in solving unemployment problems in the country

(5) That enough classrooms be provided for academic work and study.

\section{Suggestion For Further4 Research}

A study should be conducted to determine how graduates of the programme can be assisted to establish their own business.

\section{References}

[1] Central Bank of Nigeria, CBN (2012). Economic and Financial Review of Nigerian economy 2012 by Central Bank of Nigeria, Volume 12 page16

[2] Evans A, Adams S. (2009) Distinguishing Limited Commitment from Moral Hazard in Models of Growth with Inequality, in: Federal Reserve Bank of Chicago, Federal Republic of Nigeria FRN, (2000): Obasanjo"s Economic Direction 1999- 2003. Pp.1518. Dawn Functions Nigeria Limited, pp.15-18.

[3] Granjroger E. (2007), Secretarial Education in an Era of ICT. Issues and Relevance in Secretarial Duties. First Edition Owerri Cannor Publisher

[4] National Board For Technical Education, Kaduna (2004): HND Agricultural Extension and Management Curriculum

[5] Nnaji E (2004). "Secretarial Studies in the Face of Poverty and Unemployment in Secretarial Forum Journal for the Promotion and Advancement of Secretarial Profession Vol. 1.

[6] Olopele. P. (2004)“ Reducing Poverty Through Sustainable Business Development in Book of Reading in Business Education Vol.1. No.2

[7] Ogunfuminiyi A.O (2005) “ Globalisation of Information and Strategies for Self-Employment by private in “ Forum Journal for the Promotion and Advancement of Secretarial Profession Vol. I.

[8] Okeke C. C. S. (1994), Senior Secondary Economics, Awka, Jet Publishesher 